\title{
PERAN PKG DALAM UPAYA MENINGKATKAN KOMPETENSI PEDAGOGIK PENDIDIK PAUD DI KECAMATAN JATINANGOR KABUPATEN SUMEDANG
}

\author{
Tatang Sontani ${ }^{1}$, Prita Kartika ${ }^{2}$ \\ 1, 2 IKIP Siliwangi \\ 1tatangsontani66@gmail.com
}

\begin{abstract}
ABSTRAK
Peran PKG dalam upaya Meningkatkan Kompetensi Pendidik PAUD" di Kecamatan Jatinangor Kabupaten Sumedang. Tesis. Bandung: Program Pascasarjana Sekolah Tinggi Keguruan dan Ilmu Pendidikan (STKIP Siliwangi Bandung). Penelitian ini bertujuan Penyusunan program PKG dalam upaya Meningkatkan Kompetensi Pedagogik Pendidik PAUD di Kecamatan Jatinangor Kabupaten Sumedang. Hasil dari PKG dalam upaya, "Meningkatkan Kompetensi Paedagogik Pendidik PAUD di Kecamatan Jatinangor Kabupaten Sumedang". Mengacu Undang-undang No 20 Tahun 2003 tentang Sistem Pendidikan Nasional dan Peraturan Pemerintah No 73 Tahun 1991 tentang Pendidikan Luar Sekolah, maka sejak 1998 Direktorat Pendidikan Pendidik merintis pembentukan wadah pendidikan nonformal yang diharapkan mampu mengatasi permasalahan di atas. Lembaga pendidikan non formal tersebut diberi nama Pendidikan Anak Usia Dini (PAUD)Penelitian ini termasuk penelitian deskriptif dengan pendekatan kualitatif . Teknik pengumpulan data menggunakan pedoman wawancara, observasi dan dokumentasi. Berdasarkan pembahasan hasil penelitian maka kesimpulan penelitian penelitian ini terbagi menjadi dua yaitu menfaat secara teroritis dan secara praktis. Secara teoritis diharapkan akan adanya penambahan wawasan bagi para pendidik PAUD dalam melaksanakan proses pembelajaran baik pengetahuan dan keterampilannya merancang pembelajaran yang sesuai dengan tahap perkembangan dan pertumbuhan anak usia dini. Sehingga akan terjalin hubungan emosional antara pendidik PAUD dengan warga belajar (anak-anak) yang penuh keharmonisan, kehangatan, keakraban serta penuh kasih sayang yang pada gilirannya akan tercipta Sumber Daya Manusia (SDM) yang bermutu untuk masa yang akan datang.Manfaat secara praktis diharapkan akan bermanfaat secara langsung dalam pelaksanaan dilapangan baik untuk peserta didik (anak-anak), lembaga Pendidikan PAUD, dan para pengelola Pendidikan PAUD.
\end{abstract}

Key Word : Pusat Kegiatan Guru, Kompetensi Pedagogik

\section{A. PENDAHULUAN}

Begitu pentingnya pendidikan anak usia dini sebagai upaya menyiapkan Sumber Daya Manusia (SDM) yang unggul di masa yang akan datang, Pemerintah bersamaan dengan hari puncak anak nasional secara resmi melalui Presiden Republik Indonesia tanggal 23 Juli 2003 mencanangkan pelaksanaan pendidikan anak usia dini di seluruh Indonesia. Dengan demikian peristiwa itu hendaknya menjadi sumber semangat bagi seluruh 
komponen bangsa untuk menyelenggarakan pendidikan secara professional guna memenuhi hak hak anak.

Salah satu strategi peningkatan mutu pendidik PAUD yang telah diberlakukan selama ini adalah melalui pengembangan Pusat Kerja Gugus (PKG).Upaya peningkatan mutu pendidik seperti yang dipersyaratkan dalan UU No. 14 Tahun 2005 tentang dosen dan pendidik, menjadikan PKG sebagai bagian terpenting yang strategis. Hal ini di dasarkan kepada dua pemikiran ;Pertama gugus merupakan wadah berkumpulnya para pendidik PAUD pada level bawah dan paling memungkinkan bagi para tenaga pendidik untuk dapat berinteraksi dan berdiskusi secara cepat dalam mencari solusi terhadap permasalahan keseharian yang di hadapai di sekolah atau lembaga PAUD, Kedua gugus dapat ditingkatkan perannya dan fungsi sebagai wahana pembinaan profesi atau bengkel bagi tenaga pendidikdan pengelola/kepala lembaga Paud oleh unsur dan instansi terkait.

Peran PKG dalam meningkatkan kompetensi pendidik PAUD sangat penting karena sebagai pusat kegiatan kerja gugus yang mewadahi koordinasi antara gugus yang melaksanakan kegiatan pembinaan bagi seluruh anggota gugus, sebagai koordinator antara gugus, sarana pembinaan seluruh anggota gugus, bengkel kerja dalam peningkatan mutu layanan PAUD serta sebagai pusat informasi terkait dengan perubahan kebijakan, pengetahuan terkini, dan hal-hal lain yang terkait dengan kegiatan penyelenggaraan PAUD.

Adapun kondisi objektif di lapangan saat ini bahwa lembaga paud berkembang bagaikan jamur dimusim hujan pada saat ini dari data yang tercatat dalam Dapodik jumlah lembaga Paud 24.923 lembaga, jumlah tenaga pendidik 101.904 orang, dari data tenaga pendidik tersebut di atas $55 \%$ berijajah SLTP dan SMA, kondisi ini sangat memprihatinkan sehingga perlu adanya upaya-upaya yang sangat strategis untuk meningkatkan kompetensi para tenaga pendidiknya baik dari segi pengetahuan , ketrampilan dan sikap yang sesuai dengan yang diharapkan.

Permasalahannya sampai saat ini adalah bagaimana meningkatan kompetensi pendidik PAUD. Oleh karena itu, selama ini proses pembelajaran yang dilaksanakan pada PAUD secara umum dilakukan oleh para pendidik yang tidak memiliki kualifikasi pendidik, seperti dari lulusan SLTP, SLTA dan S1 dari non kependidikan. Dengan demikian perlu adanya peningkatan mutu melalui dibentuknya Pusat Kerja Gugus yang tersebar di wilayah masing masing daerah sebagai alternatif dalam upaya peningkatan mutu serta kompetensi pendidik PAUD yang mengarah pada tingkat kompetensi pendidik dalam konteks pembelajaran pendidikan usia dini.

Berdasarkan analisis situasi pendidikan nasional di Indonesai, pemerintah yang telah menetapkan empat tahapan pembangunan pendidikan formal dan pendidikan nonformal, yang saling berkaitan.Pemerataan kualitas yang dilakukan secara efektif, efesien serta bertanggung jawab. Dengan demikian, sistem pendidikan nasional diharapkan dapat meningkatkan daya saing bangsa dengan menghasilkan lulusan yang mandiri, bermutu, terampil, akhli dan professional, mampu belajar sepanjang hayat serta memiliki keterampilan yang dapat membantu dirinya dalam menghadapi berbagai tantangan dan perubahan. 
Pendidikan memiliki posisi strategis dalam menghadapi tuntutan dan perkembangan dunia yang memasuki era globalisasi, karena pendidikan memiliki tujuan untuk mengembangkan potensi yang ada pada manusia, sesuai dengan Undang-Undang No. 20 tahun 2003 tentang Sitem Pendidikan Nasional, bahwa jalur pendidikan di Indonesia dibagi menjadi tiga jalur, yaitu Pendidikan Formal, Pendidikan Nonformal dan Pendidikan Informal. Melalui ketiga jenis pendidikan ini diharapkan potensi peserta didik berkembang sehingga menjadi manusia Indonesia yang beriman, bertakwa pada Tuhan Yang Maha Esa, berakhlak mulia, sehat berilmu, cakap, kreatif, mandiri, dan menjadi warga Negara yang demokratis, serta bertanggung jawab.

Apabila Sistem Pendidikan Nasional dicermati secara seksama, jelas terlihat pembangunan disektor pendidikan ditujukan untuk membangun manusia yang berkualitas yang indikatornya terungkap jelas didalamnya. Dimana sumber daya manusia ini selalu berperan aktif dan menduduki posisi yang dominan dalam setiap kegiatan organisasi karena sebagai perencana,pelaku serta sebagai penentu keberhasilan dalam mencapai tujuan. Sumber daya manusia merupakan asset penting apabila manusia itu sendiri memiliki keilmuan untuk memberdayakan sumber daya lain yang dapat dijadikan fasilitas dalam melakukan kegiatan. Setiap orang akan memperoleh keilmuan apabila mendapat layanan pendidikan. Permasalahan saat ini adalah kesiapan sektor pendidikan dalam mengupayakan secara optimal seluruh perangkat dan komponennya untuk mewujudkan manusia berkualitas dengan indikator seperti yang dikehendaki UU No. 20 Tahun 2003 Sistem Pendidikan Nasional.

Kemampuan sektor pendidikan dalam mewujudkan manusia-manusia berkualitas, dapat dilihat dari hasil yang diperoleh setiap orang melalui pengalaman belajar yang dilaluinya. Tantangan dan permasalahan yang muncul dalam kehidupan menjadi wahana untuk memanfaatkan kemampuan yang diperoleh dari pengalaman belajar tersebut, sehingga seseorang meiliki kesiapan dan kemampuan dalam menghadapi berbagai persoalan kehidupannya.

Definisi pendidikan nonformal atau Pendidikan Luar Sekolah telah dikemukakan oleh beberapa ahli.Pada umumnya definisi yang disampaikan mengukap bahwa Pendidikan Nonformal merupakan salah satu bentuk pendididkan yang diperlukan guna mengadakan peningkatan pengetahuan, sikap dan keterampilan warga belajar. Colleta (1975) menyebutkan bahwa :

Pendidikan Nonformal atau Pendidkan Luar Sekolah adalah tranmisi pengetahuan, keterampilan dan sikap yang bertujuan dan sistematik (dengan penekanan pada peningkatan keterampilan) diluar teknologi pendidikan persekolahan formal, dengan suatu susunan struktur waktu, tempat, sumbersumber dan warga belajar yang beragam, akan tetapi terarah. (Trisnamansyah,S 1992:57)

Definisi tersebut dapat disimpulkan bahwa pendidikan nonformal/Pendidikan Luar Sekolah merupakan usaha pendidikan yang terorganisir dan sistimatis serta dilaksanakan di luar sistem persekolahan untuk memperoleh, dan mengembangkan pengetahuan, sikap dan keterampilan bagi setiap warga belajar.Pendidikan Nonformal menjadi penting artinya apabila dikaitkan dengan pemberian bekal keterampilan bagi calon tenaga kerja melalui latihan keterampilan atau latihan untuk menangani permasalahan ketenagakerjaan di Indonesia. Dalam kaitan ini bahwa kegiatan 
pendidikan ditujukan untuk mencerdaskan dan mengembangkan berbagai potensi manusia, namun demikian dalam usaha mewujudkan harapan tersebut di atas masih banyak mengahadapi berbagai kendala antara lain minimnya pengetahuan, lemahnya pendidikan serta rendahnya kualitas dan kuantitas dan kualitas sumber daya manusia para penyelenggara pendidikan. Sebagaimana dikemukakan oleh Sudjana, D (1993/2006;100) bahwa :

Dalam kegiatan belajar sikap, upaya sumber belajar ialah membantu warga belajar untuk mengembangkan perubahan sikap.Untuk itu kegiatan belajar perlu dirancang dengan baik dan memuat tujuan belajar, bahan belajar dan teknik yang cocok untuk mengembangkan perubahan sikap itu.Kegiatan belajar untuk mengubah sikap memang lebih sulit dibandingkan dengan kegiatan belajar keterampilan atau pengetahuan.

Menurut Abdullhak, I (1996:34) bahwa sikap dipelajari melalui suatu proses seperti juga pengalaman, instruksi langsung, identifikasi dan peran yang harus kita lakukan dalam bertingkah laku, oleh karena itu sikap dapat berubah dan dimodifikasi.

Berdasarkan uraian di atas, maka sangat perlu mengadakan suatu penelitian untuk memberikan solusi dengan keberadaan dilapangan sehingga proses pelaksanaan pembelajaran di pendidikan anak usia dini tidak salah sasaran. Penulis mencoba akan mengadakan penelitian dengan judul "Peran PKG dalam upaya Meningkatkan Kompetensi Pendidik PAUD” di Kecamatan Jatinangor Kabupaten Sumedang."

\section{B. TINJAUAN PUSTAKA}

1. Peran PKG dalam Upaya Meningkatkan Kompetensi Pedagogik Pendidik PAUD a. Latar Belakang

Pendidikan merupakan hak setiap warga Negara, pendidikan merupakan merupakan investigasi indakator dari ciri suatu bangsa yang maju. Oleh karena itu pendidikan sangat penting bagi setiap masyarakat, apalagi menghadapi era globalisasi yang tanpa dibatasi oleh jarak dan waktu.

Untuk mencapai hal tersebut di atas, maka pemerintah telah memberikan fasilitas jalur penyelenggara pendidikan yang diatur dengan undang-undang system pendidikan nasional nomor 20/2003 yaitu ada tiga jalur penyelenggara pendidikan, pendidikan formal, pendidikan non formal dan informal. Pendidikan Non Formal (PNF) merupakan pendidikan yang dilaksanakan melalui pendidikan luar sekolah. Pendidikan anak usia dini (PAUD) merupakan salah satu kegiatan yang dilaksanakan oleh bidang PNF.

Dalam rangka menuju penyelenggaraan yang berkualitas perlu ditingkatkan profesionalisme tenaga kependidikan non formal khususnya pendidik PAUD melalui berbagai cara dan upaya sehingga pendidikan non formal dapat diterima dimasyarakat serta dapat menghasilkan dasar pendidikan sejak dini melalui pembeajaran anak usia dini.

Dari kenyataan dilapangan para tenaga kependidikan PNF khususnya tenaga pendidik PAUD secara kualitas hampir sama dengan tenaga kependidikan formal, namun untuk mengetahui hal tersebut sangatlah sulit jika tidak difasiliatasi dengan suatu cara yang tepat. Pelatihan Pendidik PAUD merupakan salah satu upaya untuk meningkatkan mutu 
layanan pendidikan non formal serta peningkatan kompetensi pendidik PAUD sehingga diharapkan standar nasional pendidikan secara optimal tercapai melalui layanan anak usia dini.

\section{Konsep Dasar Gugus Paud \\ a. Gugus Paud}

Gugus PAUD difungsikan sebagai sarana dialog antara semua pihak yang peduli dengan PAUD. Gugus PAUD ini juga diharapkan mampu menyerap berbagai perspektif dan aspirasi tentang PAUD untuk diolah menjadi acuan dalam pengembangan kebijakan oleh pemerintah dan pengembangan karir pendidik PAUD. Selain itu menjadi landasan dalam menetapkan rencana tindakan untuk pengembangan PAUD

\section{b. Tujuan Gugus Paud}

Tujuan Umum

Meningkatkan kinerja pembina pendidikan, pedidik dan tenaga kependidikan dalam mengelola lembaga gugus PAUD Terpadu dalam rangka maju bersama dalam mewujudkan pengelolaan gugus PAUD Terpadu yang efesien dan efektif

Tujuan Khusus

Meningkatkan mutu pendidikan PAUD sesuai dengan standar Nasional

\section{c. Fungsi Gugus PAUD}

1. Wadah pembinaan profesional

2. Sarana untuk saling bertukar informasi dan saling membelajarkan

3. Sebagai bengkel kerja dalam penyediaan dan pengembangan kreasi dan inovasi

4. Sarana pembinaan kelembagaan PAUD secara efektif dan efisien

\section{a. Siapa Yang Menginisiasi ?}

Gugus PAUD diinisiasi oleh Pendidik bersama pengawas dan penilik (Dinas Pendidikan Kecamatan/UPTD)? pendekatan mix; top-down \& bottom up,untuk memunculkan rasa kepemilikan terhadap gugus sehingga terjamin kesinambungan gugus PAUD

\section{e. Bagaimana Prosedur Pembentukan Gugus Paud ?}

1. Mensosialisasikan Pentingnya pembentukan Gugus PAUD kepada lembaga PAUD di tingkat kecamatan

2. Melakukan inventarisasi lembaga PAUD di tingkat kecamatan

3. Pemetaan Lembaga PAUD di tingkat kecamatan

4. Pembentukan Gugus/struktur organisasi gugus

5. Yang memfasilitasi Proses pembentukan Gugus PAUD : pendidik dan pengawas/penilik (UPTD)

\section{f. Peran Gugus Paud}

1. Sebagai wadah dalam meningkatkan mutu pendidik dan tenaga kependidikan. Yang termasuk pendidik, yaitu; pengasuh, guru pendamping, guru. Sedangkan Tenaga Kependidikan, yaitu; pengawas, penilik, pengelola, kepala sekolah, administrasi dan petugas kebersihan

2. Sebagai Media Pembelajaran yg memfasilitasi kepentingan pengembangan karir pendidik PAUD 
3. Sebagai learning centre dan learning exchange untuk menyamakan persepsi, berbagi pengalaman, tukar fikiran, dst

4. Sebagai bengkel kerja dalam penyediaan dan pengembangan kreasi dan inovasi

5. Sebagai media pengembangan bahan ajar

6. Sebagai sarana dialog antara semua pihak yg peduli dengan PAUD

7. Sebagai pusat informasi

\section{g. Peran Mitra}

Organisasi mitra (HIMPAUDI, IGTK, BPTKI, 'Aisyiyah, Muslimat NU, dll) berperan sebagai "motivator", mendorong terbentuknya Gugus PAUD di tingkat kecamatan

\section{h. Peran SKB}

a. melaksanakan program pemberdayaan Guru Inti PAUD

b. mengupayakan pelaksanaan program yang berkualitas dan menjalin serta mengembangkan kemitraan dengan instansi terkait,

c. melakukan koordinasi dengan dinas pendidikan kabupaten/kota ,kecamatan dan forum/asosiasi PTK PAUD

d. melakukan pemantauan dan pengendalian internal

e. mengupayakan dan menindaklanjuti agar program pemberdayaan guru inti PAUD dapat menjadi program yang dibiayai melalui APBD setempat.

\section{i. Keorganisasian}

Gugus PAUD beranggotakan:

1) Guru TK, KB, TPA, SPS

2) Kepala dan Pengelola PAUD

\section{j. Kedudukan}

1) Bagian wilayah kecamatan

\section{k. Pembentukan}

1) Oleh anggota dikukuhkan oleh Kepala UPTD Kecamatan

\section{Pembinaan}

1) Pembina Administratif : KUPTD

2) Pembina Teknis: Penilik dan Pengawas PAUD

m. Keorganisasian

1) PAUD Inti

2) PAUD Imbas

3) Kepengurusan

4) Program Kerja

\section{n. Syarat PAUD Inti}

1) Letak mudah dijangkau

2) Memiliki pendidik yang memenuhi kualifikasi sesuai Standar PAUD.

3) Memiliki inovasi

4) Memiliki fasilitas dan sumber belajar yang memadai.

5) Memiliki manajemen PAUD yang baik. 


\section{o. Mekanisme}

1) Mekanisme pemberdayaan/pembinaan Pendidik dan Tenaga Kependidikan di setiap gugus dilaksanakan secara berjenjang dan berkelanjutan oleh guru inti (lihat skema)

2) Guru inti adalah guru yg memiliki kemampuan untuk membina guru sebaya minimal 4 orang dalam 1 gugus paud (ratio $1: 4$ ) dengan masing-masing jenis layanan (layanan TK, KB, TPA, SPS)

3) Program Gugus PAUD : program bersifat umum dan program bersifat khusus

4) Program yang bersifat umum ; program yg dilakukan semua layanan dalam bentuk pertemuan secara menyeluruh, yang disi dengan sharing permasalahan dan merumuskan solusinya. Apabila permasalahan tidak bisa diselesaikan dapat mengundang narasumber dari luar gugus yang berkompoten. Program umum dilaksanakan setiap 3 bulan sekali

5) Program yg bersifat khusus program yang dilakukan oleh guru inti kepada guru sebayanya, dilakukan dalam kelompok kecil sesuai ratio guru inti terhadap guru sebayanya dalam 1 gugus (ratio 1 : 4). Program khusus dilaksanakan setiap bulan sekali

p. Bentuk Kegiatan (Program Khusus)

1) Pertemuan Rutin minimal 1 bulan sekali

2) Bedah buku

3) Kajian kurikulum

4) Micro theaching

5) Inovasi pembelajaran

6) Pembuatan APE

7) Membuat buku cerita anak

8) Mengarang lagu, membuat syair

q. Bentuk Kegiatan (Program Umum)

1) Seminar/workshop/studi banding

2) Desiminasi bahan ajar

\section{r. Program Kerja Gugus}

1) Penyusunan Visi, dan Misi Gugus PAUD

2) Program pengelolaan manajemen Gugus PAUD serta tertib administrasi Gugus PAUD.

3) Program peningkatan Mutu Pendidikan Gugus PAUD

4) Program Pengembangan Gugus PAUD

5) Menindaklanjuti hasil pertemuan di PKG

6) Program Evaluasi Gugus PAUD

\section{s. Pelaksanaan Program Kerja}

1) pertemuan rutin anggota minimal 1 kali dalam satu bulan.

2) Waktu pertemuan diupayakan di luar waktu layanan PAUD.

3) Tempat kegiatan pertemuan di PAUD Inti atau tempat lain yang disepakati bersama.

4) Dapat mendatangkan nara sumber dari instansi atau gugus lain.

5) Disesuaikan dengan kegiatan PKG

\section{t. Pola Pembinaan Gugus Paud}

Pola Pembinaan Gugus PAUD 
Pembinaan Gugus PAUD dilaksanakan melalui prinsip pembinaan, pemberdayaan, dan kemitraan dalam mencapai tujuan bersama. Hal ini perlu ditunjang dengan struktur pembinaan yang mencerminkan pola hubungan kerja antara unsur-unsur terkait.

\section{Tingkat Pusat}

Pembinaan gugus tingkat pusat dilaksanakan oleh Direktorat Pembinaan PAUD, Yaitu :

a. Perumusan kebijakan manajemen Gugus PAUD.

b. Pelaksanaan pembinaan secara berjenjang.

c. Peningkatan kemitraan dengan organisasi penyelenggara PAUD, dan organisasi profesi dimana pendidik PAUD bernaung.

d. Dukungan fasilitasi penyelenggaraan Gugus PAUD.

\section{Tingkat Provinsi}

Pembinaan melalui Gugus PAUD tingkat provinsi dilaksanakan oleh Dinas Pendidikan Provinsi dan Bidang Pendidikan Pendidikan Nonformal dan Informal yang mengenai PAUD, dalam bentuk :

a. Pemantauan dan evaluasi pelaksanaan pembinaan di lapangan.

b. Pengikut sertaan dan pengkoordinasian instansi/lembaga kependidikan yang relevan untuk menyumbangkan tenaga ahlinya.

c. Koordinasi kemitraan dengan organisasi penyelenggara PAUD, dan organisasi provesi dimana pendidik PAUD bernaung.

\section{Tingkat Kabupaten/Kota}

Pembinaan Gugus PAUD pada tingkat kabupaten/kota dilaksanakan oleh Dinas Pendidikan dan Bidang pendidikan Nonformal kabupaten/kota yang menangani PAUD melalui kegiatan :

a. Melaksanakan pembinaan program di tingkat kecamatan.

b. Membantu menyampaikan informasi kepada masyarakat tentang pelaksaaan kegiatan pembinaan Gugus PAUD.

c. Mengkoordinasikan kerjasama dengan instansi/lembaga terkait untuk membina pelaksanaan pembinaan Gugus PAUD.

\section{Tingkat Kecamatan}

Pembinaan Gugus PAUD tingkat kecamatan dilaksanakan oleh UPDT (Unit Pelaksanaan Tingkat Daerah), tanggung jawab administrasinya dilaksanakan secara teknis oleh pengawas TK/SD. Kelompok kerja pendidik (KKG), Kelompok Kerja Kepala/Pengelola (KKKP), Pengawas TK/SD merupakan penggerak maju mundurnya suatu Gugus PAUD sehingga Gugus PAUD dapat difungsikan sebagai mestinya.

\section{Pemantauan, Penilaian, Pelaporan dan Tindak Lanjut}

a. Pemantauan, penilaian, pelaporan, dan tindak lanjut dilaksanakan secara terus menerus dan berkelanjutan. Mekanisme pelaksanaannya disesuaikan dengan tingkat pembinaan dan dilaksanakan secara berjenjang, antara lain melalui pelaksanaan lomba Gugus PAUD.

b. Semua hasil pemantauan dan penilaian program yang baik maupun kurang harus dilaporkan dan ditindaklanjuti sehingga dapat menjadi bahan penyusunan program pembinaan pada periode berikutnya.

\section{Pusat Kerja Gugus (PKG) Paud Kecamatan}


Pengertian:

Wadah koordinasi antar gugus yang melaksanakan kegiatan pembinaan bagi seluruh anggota gugus di wilayah kecamatan. Pusat Kerja Gugur PAUD Kecamatan berfungsi :

a. Koordinator antar gugus.

b. Wadah pembinaan seluruh anggota gugus

c. Bengkel kerja peningkatan mutu layanan PAUD

d. Pusat informasi terkait dengan perubahan kebijakan, pengetahuan terkini, dan halhal lain yang terkait dengan kegiatan PAUD.

\section{METODE PENELITIAN}

Metode penelitian yang digunakan dalam penelitian ini adalah metode deskriptif dengan pendekatan kualitatif yaitu berusaha untuk menganalisis dan meneliti masalah yang terjadi pada masa sekarang. Hal tersebut sejalan dengan pandangan Sugiyono (2014 : 8) yang mengemukakan bahwa :

Metode penelitian kuantitatif yang dapat diartikan segagai metode penelitian yang berlandaskan pada filsafat positivisme, digunakan untuk meneliti pada populasi atau sampel tertentu, pengumpulan data menggunakan instrument penelitian, analisis data bersifat kualitatif/stattistik, dengan tujuan untuk menguji hipotesa yang telah ditetapkan.

Beranjak dari pemahaman pandangan di atas sifat-sifat yang terdapat dalam metode deskriptif yaitu bahwa metode deskriptif memusatkan pemecahan masalah yang ada pada masa sekarang atau masalah yang aktual. Artinya menunjukan bahwa hasil penelitian ini merupakan gambaran masalah yang terjadi pada saat penyelenggaraan penelitian dilakukan. Selanjutnya bahwa metode deskriptif pula memiliki tahapan yang diawali dengan pengumpulan data yang kemudian disusun, dijelaskan dan kemudian dianalisa sehingga dapat diambil kesimpulan.

Penelitian ini menggunakan metode deskriptif yang termasuk ke dalam studi kasus, dengan instrumen pengukuran bersifat penelitian kualitatif. Prof. Dr. Sugiyono (2014 : 35) mengemukakan pula bahwa:

Rumusan masalah deskriptif adalah suatu rumusan masalah yang berkenaan dengan pertanyaan terhadap keberadaan variable mandiri, baik hanya pada satu variable atau lebih (variable yang berdiri sendiri). Jadi dalam penelitian ini peneliti tidak membuat perbandingan variable itu pada sampel yang lain. Peneliti semacam ini untuk selanjutnya dinamakan peneliti deskriptif.

Metode deskriptif tidak terbatas hanya sampai kepada pengumpulan data saja, akan tetapi meliputi analisis dan interpretasi tentang arti data itu. Hakekat dari suatu fenomena bagi penganut metode kualitatif adalah totalitas, ketepatan interpretasi bergantung kepada ketajaman analsisi, objektivitas, sistematik dan sistemik, bukan kepada statistika dengan menghitung berapa besar probabilitasnya bahwa peneliti benar dalam interpretasinya.

Sedangkan studi kasus menurut Izzak Latunussa (1989 : 56) adalah : "Penelitian terhadap satu individu, satu kelompok atau satu lembaga secara mendalam dan terperinci". Penelitian ini dalam proses penggunaannya memiliki acuan tertentu, atau dengan kata lain memiliki beberapa karakteristiknya. Adapun karakteristik tersebut menurut Lexy J. Moleong (1994: 4 - 6) adalah : 
1. Latar alamiah

2. Manusia sebagai alat

3. Metode kualitatif

4. Analisis data secara induktif

5. Teori dan dasar

6. Deskriptif

7. Lebih mementingkan proses daripada hasil

8. Adanya batas yang ditentukan oleh focus

9. Adanya kriteria khusus untuk keabsahan data

10. Desan yang bersifat sementara

11. Hasil penelitian dirundingkan serta disepakati bersama

Berdasarkan tujuan penelitian dan pendekatan kualitatif, maka untuk mendapatkan informasi yang dibutuhkan peneliti sendiri sebagai penggali data atau informasi langsung dari subjek penelitian. Dalam proses pengumpulan data peneliti melakukan proses yang berbentuk siklus, yang berlangsung secara kontinyu. Adapun siklus tersebut dibagi dalam tiga tahapan, sebagaimana yang dikemukakan oleh Sanafiah Faisal (1990: 45), yaitu :

1. Eksplorasi yang meluas atau menyeluruh dan biasanya bergerak di tingkat permukaan

2. Eksplorasi secara terfokus atau terseleksi untuk mencapai tingkat kedalaman dan kerincian tertentu

3. Mengecek atau mengkonfirmasikan hasil/temuan dari penelitian

Berkaitan dengan masalah penelitian yang dilakukan ini maka melalui penentuan metode yang digunakan yaitu metode penelitian deskriptif diharapkan dapat menghasilkan dan memperoleh informasi yang tepat dan gambaran yang lengkap serta faktual mengenai manajemen lembaga kursus dalam meningkatkan kompetensi PTK PAUD memasuki KBM pada program PAUD di kec. Jatinanggor Kabupaten Sumedang.

\section{PEMBAHASAN}

Penelitian ini mengembangkan serangkaian program yang bertujuan untuk melakukan evaluasi hasil mencakup kualitas peserta didik setelah mengikuti proses pelatihan yang dinilai dari perubahan tingkah laku peserta dari ranah afeksi, kognisis dan psikomotor. Ranah afeksi mecakup sikap, aspirasi, perasaan, dorongan, nilai, dan lain sebagainya. Ranah kognisi mencakup pengetahuan, penguasan dan pemahaman. Ranah psikomotor meliputi skill yang berkenaan dengan ketrampilan produktif, teknik, fisik, sosial, manajerial, dan/atau intelek. Ketiga ranah tersebut berkaitan dengan materi/bahan belajar yang telah dipelajari dan kebermaknaannya dalam kehidupan peserta didik.

Dalam penelitian ini dapat diketahui bahwa program kerja guru melalui KKG dapat berjalan dengan baik. Hal ini didukung dengan proses kerja yang dilakukan secara berkelompok sehingga memberikan kesempatan kepada para Perubahan tingkah laku yang dicapai setelah mengikuti pelatihan Pendidik PAUD, sejalan dengan manfat secara umum suatu pelatihan yaitu Kegunaan penelitian ini terbagi menjadi dua yaitu menfaat secara teroritis dan secara praktis. Secara teoritis diharapkan akan adanya penambahan wawasan bagi para pendidik PAUD dalam melaksanakan proses pembelajaran baik pengetahuan dan keterampilannya merancang pembelajaran yang sesuai dengan tahap perkembangan dan pertumbuhan anak usia dini. Sehingga akan 
terjalin hubungan emosional antara pendidik PAUD dengan warga belajar (anak-anak) yang penuh keharmonisan, kehangatan, keakraban serta penuh kasih sayang yang pada gilirannya akan tercipta Sumber Daya Manusia (SDM) yang bermutu untuk masa yang akan datang. Manfaat secara praktis diharapkan akan bermanfaat secara langsung dalam pelaksanaan dilapangan baik untuk peserta didik (anak-anak), lembaga Pendidikan PAUD, dan para pengelola Pendidikan PAUD.

\section{E. KESIMPULAN}

Berdasarkan pembahasan hasil penelitian maka kesimpulan penelitian ini secara umum untuk memperoleh informasi tentang Peran PKG di Kecamatan Jatinangor Kabupaten Sumedang." dalam upaya peningkatan kompetensi Paedagogik pendidik PAUD sebagai berikut :

1. Penyusunan program PKG dalam upaya Meningkatkan Kompetensi Pedagogik Pendidik PAUD di Kecamatan Jatinangor Kabupaten Sumedang." .

2. Proses pelaksanaan PKG dalam upaya Meningkatkan Kompetensi Paedagogik Pendidik PAUD di Kecamatan Jatinangor Kabupaten Sumedang."

3. Peran PKG dalam upaya Meningkatkan Kompetensi Paedagogik Pendidik PAUD di Kecamatan Jatinangor Kabupaten Sumedang." .

4. Hasil dari PKG dalam upaya Meningkatkan Kompetensi Paedagogik Pendidik PAUD di Kecamatan Jatinangor Kabupaten Sumedang."

\section{F. DAFTAR PUSTAKA}

Abdulhak, Ishak. (1996). Metodologi Pembelajaran Orang Dewasa. Bandung : Andira. Arikunto, Suharsimi. (1993). Prosedur Penenlitian Suatu Pendekatan Praktek, Jakarta. Rieneka Cipta

Disdiknas. (1994). Menyusun Program Belajar Mengajar. Jakarta. (1994). Pendidikan Luar Sekolah. Jakarta.

Sugiono, ( 2014 ). Metode Penelitian Pendidikan, Bandung Alfabeta.W

Sudjana, D. (2003). Pendidikan Luar Sekolah Wawasan, Sejarah Perkembangan, Falsafah dan Teori Pendukung Azas. Bandung: Falah Production Depdiknas. (2007). Pedoman Permainan Berhitung Permulaan di Taman 